\title{
Hematological Parameters in Subchronic Toxicity Test of Black Garlic Ethanol Extract in Rats
}

\author{
Ellen Stephanie Rumaseuw ${ }^{1 *}$, Yoppi Iskandar², Eli Halimah³ \\ ${ }^{1}$ Department of Phytochemical, Saint Borromeus College of Health Sciences, Jl. Parahyangan Lot 8 Block B No.1, Kota Baru Parahyangan, \\ Cipeundeuy, Padalarang, Cipeundeuy, Padalarang, West Bandung Regency, West Java 40553, Indonesia \\ 2Department of Pharmacy Biology, Faculty of Pharmacy, Universitas Padjadjaran, J. Raya Bandung Sumedang Km 21, Jatinangor, Sumedang, \\ West Java 45363, Indonesia \\ 3Department of Pharmacology and Clinical Pharmacy, Faculty of Pharmacy, Universitas Padjadjaran, Jl. Raya Bandung Sumedang Km 21, \\ Jatinangor, Sumedang, West Java 45363, Indonesia
}

\section{Abstract}

The community has used black garlic since ancient times for hypercholesterolemic. Until now, people still consume both raw and cooked black garlic. Black garlic is included in processed garlic products. People on the Asian continent have used black garlic for the past 10 years. This study aims to determine the sub-chronic toxic effect of black garlic ethanol extract on male and female white rats using hematological parameters consisting of hematocrit, hemoglobin, erythrocytes, leukocytes, platelets, $\mathrm{MCV}, \mathrm{MCH}$, and $\mathrm{MCHC}$. This research method was a completely randomized design with the administration of ethanolic extract of black garlic to rats in 5 treatment groups, including a negative control group, a dose group of $1000 \mathrm{mg} / \mathrm{kg} \mathrm{BW}$, a dose group of $2000 \mathrm{mg} / \mathrm{kg} \mathrm{BW,} \mathrm{a}$ negative control satellite group and a satellite group with a dose of $2000 \mathrm{mg} / \mathrm{kg}$ BW. Data were analyzed statistically using one-way ANOVA with a $95 \%$ confidence level and SPSS version 20 . The study results of black garlic ethanol extract showed no significant effect or were at normal levels on hematological parameters. Therefore, it can be concluded that the ethanolic extract of black garlic is safe for human use as a treatment for hypercholesterolemia.

\section{Keywords: Black Garlic; Hematology; Subchronic Toxicity Test}

\section{INTRODUCTION}

The community has used black garlic for hypercholesterolemia. Until now, people still consume both raw and cooked black garlic. Black garlic is one of the processed garlic products. People on the Asian It has a sweet, chewy taste and a distinctive aroma. $^{1} \quad$ Black garlic contains carbohydrates, amino acids, total polyphenols, and flavonoids. ${ }^{2}$ In addition, there are changes in several bioactive compounds such as S-allyl cysteine,

\section{Data of article}

Received : 01 Nov 2021

Reviewed : 24 Dec 2021

Accepted : 17 Feb 2022

\section{DOI}

10.18196/jfaps.v2i1.13755

Type of article:

Research

\footnotetext{
*Corresponding author, e-mail: rumaseuwellen@gmail.com
}

vitamins, phenolic acids and flavonoids in black garlic during the heating process. Sallyl cysteine, one of the main components of sulfur-containing amino acid compounds, is five to six times higher than fresh garlic. ${ }^{3}$ The decrease in alliin content in black garlic is that alliin is converted to S-allyl cysteine. S-allylmercapto-cysteine, arginine and other compounds are not defined when the heating process. ${ }^{4}$ According to the 2016 Minister of Health Regulation, garlic is included as a native plant of Indonesia that can be used as 
herbal medicine. It has conditions proven to be safe, efficacious and of good quality. ${ }^{5,6}$ The use of black garlic as a processed garlic product is a native Indonesian herbal medicine included in the herbal medicine category called jamu. Several studies of black garlic in vivo have also been carried out over the last 20 years, including Prof. Dr. Jin Ichi Sasaki in Japan, revealing that black garlic has antitumor activity. ${ }^{7}$ Black garlic initially resulted in many Japanese people producing black garlic using simple tools such as rice cookers and other heating devices so that black onions can be consumed. ${ }^{7}$ In addition to black garlic as an anti-tumor, many other activities were investigated by several researchers, such as research by Wang et al. in 2012 related to the content of black garlic, namely Sallyl-cysteine, which was found to be able to reduce $50 \%$ of the size of fibrosarcoma in mice. ${ }^{8}$ Other research also investigated that black garlic has other biological activities such as antioxidant activity, ${ }^{9}$ anticancer on human leukemic cells, ${ }^{10}$ antiobesity where black garlic is given to obese mice, ${ }^{11}$ anti-inflammatories, ${ }^{12}$ hypoallergenic, ${ }^{13}$. Research conducted by Nuristika in 2018 concluded that black garlic did not cause death in mice, so the $\mathrm{LD}_{50}$ was unknown. Another study revealed that the administration of Dayak onion ethanol extract did not affect the hematological profile in white rats. ${ }^{14}$ The development of an herbal medicinal product that has been tested in vivo, apart from toxicity testing, parameters can also be studied to obtain a toxic effect. A natural ingredient can also be investigated for its toxicity, including changes in body weight, clinical symptoms, hematological parameters, clinical biochemistry, macro pathology, histopathology, target organs, mortality, and other general or specific effects. ${ }^{15}$ Testing of a natural ingredient was carried out on a biological system such as oral subchronic toxicity testing on rats for 28 days or 90 days with five dose groups, namely the negative control group, a dose of 1000 and $2000 \mathrm{mg} / \mathrm{kg} \mathrm{BW}$, as well as the negative control satellite group and satellite group of $2000 \mathrm{mg} / \mathrm{kg}$ BW. At the end of the period of administering the test preparations, all living experimental animals were autopsied and subjected to mactopathological, hematological, clinical biochemical and histopathological observations. The test was carried out to determine the cumulative effect and reversibility effect after repeated exposure to the test preparation for a certain period. ${ }^{15}$ This study aims to identify if people with a history of hypercholesterolemia consuming black garlic continuously or in the long term causes toxic effects, as seen from the description of the blood hematology parameters.

\section{METHOD}

The research design for the oral subchronic toxicity test was a completely randomized design (CRD), in which there were treatment and control groups with homogeneous environmental factors. The research was conducted at the Phytochemical Laboratory of Santo Borromeus College of Health and the Pharmacology and Toxicology Laboratory of Padjadjaran University. This research was started from February to May 2019. The sample used was garlic (Allium sativum, $L$ ) determined in advance at the Taxonomy Laboratory of the Department of Biology, Faculty of Mathematics and Natural Sciences, Padjadjaran University. $1 \mathrm{~kg}$ of garlic was processed into black garlic by the maceration method for $5 \times 24$ hours with $70 \%$ ethanol solvent. The garlic was processed with a rice cooker at $70^{\circ} \mathrm{C}$ heating for 21 days. The preparation of tested animals used were 25 male rats and 
25 female Wistar rats with a bodyweight of approximately 100-200 grams according to the Cage Space Guidelines for Animals Used in Biomedical Research (2008), adapted for 1 week. Before carrying out subchronic toxicity testing, it is necessary to have a research code of ethics (ethical clearance) from the Research Ethics Commission of the Faculty of Medicine, the University of Padjadjaran, with number 528/UN6.KEP/EC/2019. The black garlic ethanol extract was administered for 28 days (measurement of rats' body weight) and 29 days for the negative control group, and 43 days for the satellite test examination. Hematological examination on mice took $1 \mathrm{~mL}$ of blood into a K2EDTA vacutainer tube containing $0.5 \mathrm{~mL}$ of ethylene diamine tetraacetate (EDTA). The blood was then examined using a hematological analyzer (XP-100). The data obtained included hemoglobin, erythrocytes, leukocytes, platelets, MCV, $\mathrm{MCH}$, and $\mathrm{MCHC}$. The graph was created to determine the increase in the body weight of rats. Statistical analysis of blood hematological parameter data used One Way ANOVA and SPSS version 20. The research materials included garlic obtained from Lembang-West Java. All other chemicals and reagents were sourced commercially, such as ethanol from Merck (Germany) and Pulvis Gummi Arabicum from J. Trading Co. Ltd. (Thailand). Research tools included thermostatic water bath (China), Rotary Evaporator RE 100-S Dlab (China) and Hematological Analyzer XP-100 (China).

\section{RESULTS AND DISCUSSION}

\section{Ethanol extract of black garlic}

The maceration results were revealed after being conducted for 5 days. This method was used to extract the active substance that has pharmacological activity. Hypercholesterolemia obtained a yield of $49.584 \%$, as shown in table 1.

Table 1. Yield value of black garlic ethanol extract

\begin{tabular}{ccc}
\hline $\begin{array}{c}\text { Black } \\
\text { Garlic }\end{array}$ & $\begin{array}{c}\text { Extract of } \\
\text { black garlic }\end{array}$ & $\begin{array}{c}\text { Yield value of } \\
\text { black garlic }\end{array}$ \\
\hline 1.000 gram & $\begin{array}{c}495.84 \\
\text { gram }\end{array}$ & $49.584 \%$ \\
\hline
\end{tabular}

\section{Oral subchronic toxicity test}

The graph of the weight development of male rats is shown below. In administering test preparations at a dose of $1000 \mathrm{mg} / \mathrm{kg}$ BW and $2000 \mathrm{mg} / \mathrm{kg} \mathrm{BW}$, the bodyweight development of rats fluctuated every day, as shown in Figure 1.

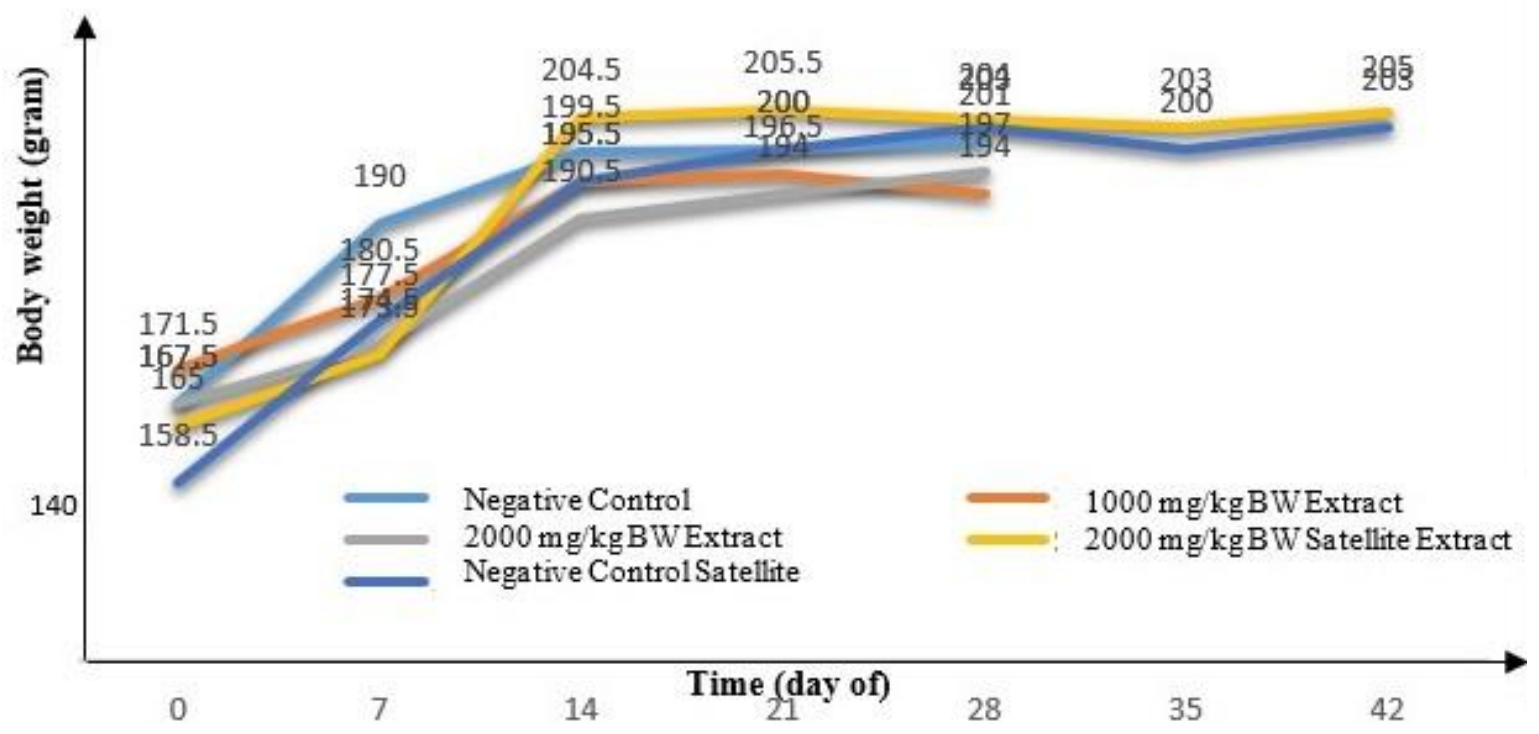

Figure 1. Bodyweight development of male rats 
There were fluctuations in the body weight of rats in the negative control group and doses of 1000 and $2000 \mathrm{mg} / \mathrm{kg}$ BW until the 28th day. An increase in body weight of rats occurred in the negative control satellite group, and the satellite dose of $2000 \mathrm{mg} / \mathrm{kg} \mathrm{BW}$ significantly until the $42^{\text {nd }}$ day. The graph of the bodyweight development of female rats is shown below. In administering test preparations at a dose of $1000 \mathrm{mg} / \mathrm{kg} \mathrm{BW}$ and 2000 $\mathrm{mg} / \mathrm{kg} \mathrm{BW}$, the bodyweight development of rats fluctuated every day, shown in Figure 2.

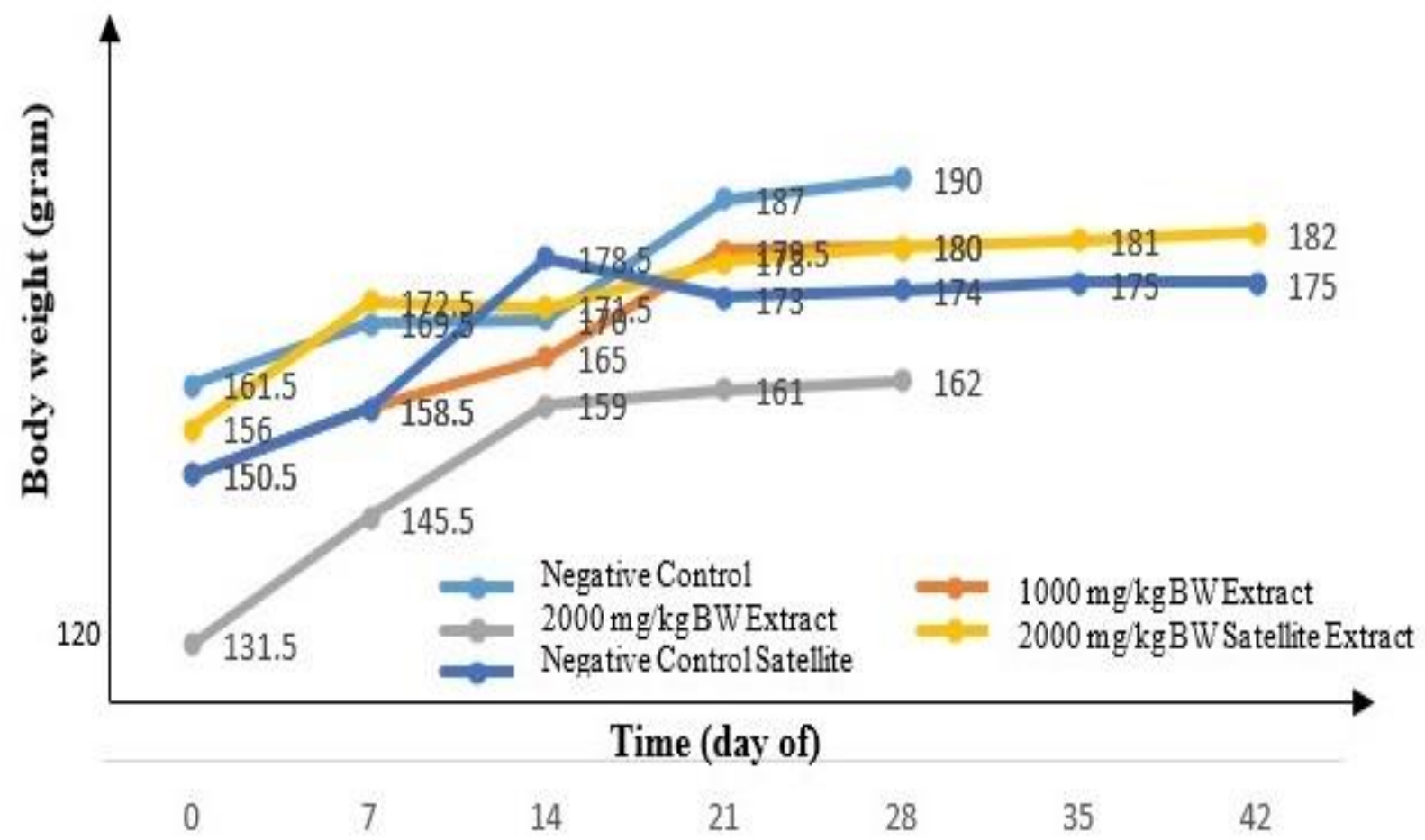

Figure 2. Bodyweight development of female rats

There were fluctuations in the body weight of female rats in the negative control group and doses of 1000 and 2000 $\mathrm{mg} / \mathrm{kg} \mathrm{BW}$ until the $28^{\text {th }}$ day. An increase in body weight of rats occurred in the negative control satellite group, and the satellite dose of $2000 \mathrm{mg} / \mathrm{kg} \mathrm{BW}$ significantly until the $42^{\text {nd }}$ day. In addition to weighing the body weight of rats, the average increase in body weight was also observed to determine the magnitude of administering black garlic ethanol extract with certain doses, as shown in Table 2.

Table 2. Average Body Weight of Male and Female Rats

\begin{tabular}{cccccc}
\hline \multirow{2}{*}{ Groups } & $\mathbf{n}$ & Male Rats & & Female Rats \\
\cline { 3 - 4 } & & & Average & & Average \\
\hline Negative Control & 5 & $191.6 \pm 14.18$ & & 5 & $175.6 \pm 12.29$ \\
\hline $1000 \mathrm{mg} / \mathrm{kg} \mathrm{BW}$ & 5 & $187.6 \pm 11.09$ & 5 & $166.7 \pm 12.97$ \\
\hline Satellite $2000 \mathrm{mg} / \mathrm{kg} \mathrm{BW}$ & 5 & $184.7 \pm 12.95$ & 5 & $151.8 \pm 13.15$ \\
\hline Satellite Negative Control & 5 & $191.07 \pm 16.87$ & 5 & $174.42 \pm 9.09$ \\
\hline
\end{tabular}

Note: $\mathrm{n}=$ Number of rats in each treatment group 
The statistical data analysis was carried out regardless of the difference in the increase in body weight of rats among groups, as shown in Table 3 .

Table 3. Result of Statistical Analysis of Body Weight of Male and Female Rats

\begin{tabular}{lccc}
\hline & \multirow{2}{*}{ Groups } & \multicolumn{2}{c}{ Statistical Analysis Results ( $\mathbf{p}>0.05)$} \\
\cline { 3 - 4 } & & Male Rats & Female Rats \\
\hline \multirow{2}{*}{ Day 1-28 } & Negative Control & ANOVA & ANOVA \\
& 1000 mg/kg BB & 0.034 & 0.345 \\
& $2000 \mathrm{mg} / \mathrm{kg} \mathrm{BB}$ & 0.144 & 0.434 \\
\hline Day 29-42 & Satellite Negative Control & 0.312 & 0.146 \\
& Satellite 2000 mg/kg BB & Kruskal Wallis & Kruskal Wallis \\
& & 0.140 & 0.337 \\
\hline
\end{tabular}

The research data were tested for normality and homogeneity using ANOVA and non-parametric analysis methods for $\mathrm{K}$ independent samples (Kruskal Wallis). If the significance is more than 0.05 ( $p>0.05$ ), there is no significant difference, and no further test is needed. If the significance is less than $0.05 \quad(p<0.05)$, a significant difference can be further identified by conducting the Tukey test. The administration of black garlic ethanol extract in the negative control group, a dose of 1000 and a dose of $2000 \mathrm{mg} / \mathrm{kg} \mathrm{BW}$ of male and female rats for 28 days, did not significantly increase the bodyweight of the tested rats (28 days) and the satellite group ( 42 days).

\section{Hematological Parameter Test}

The hematological examination was carried out to determine abnormalities in the quantity and quality of blood cells. It also examined changes in plasma that played a role in the blood clotting process and identified if there was inflammation or infection, as indicated in table 4 and table 5 below. 
Table 4. Value of Hematological Parameters Analysis of Male Rat

\begin{tabular}{|c|c|c|c|c|}
\hline Parameter & Groups & $\begin{array}{c}\text { Normal Level } \\
\text { Male }\end{array}$ & Grade Value & $\begin{array}{l}\text { ANOVA } \\
(p>0.05)\end{array}$ \\
\hline $\begin{array}{l}\text { Hemoglobin } \\
(\mathrm{g} / \mathrm{dL})\end{array}$ & $\begin{array}{c}\text { Negative Control } \\
1000 \mathrm{mg} / \mathrm{kg} \mathrm{BW} \\
2000 \mathrm{mg} / \mathrm{kg} \mathrm{BW} \\
\text { Satellite2000 } \mathrm{mg} / \mathrm{kg} \mathrm{BW} \\
\text { Satellite Negative } \\
\text { Control }\end{array}$ & $13 \cdot 7-17.6$ & $\begin{array}{l}12.5 \\
13.3 \\
14.9 \\
14.1 \\
16.8\end{array}$ & 0.259 \\
\hline $\begin{array}{c}\text { Hematocrit } \\
(\%)\end{array}$ & $\begin{array}{c}\text { Negative Control } \\
1000 \mathrm{mg} / \mathrm{kg} \mathrm{BW} \\
2000 \mathrm{mg} / \mathrm{kg} \mathrm{BW} \\
\text { Satellite } 2000 \mathrm{mg} / \mathrm{kg} \mathrm{BW} \\
\text { Satellite Negative } \\
\text { Control }\end{array}$ & $39.6-52.5$ & $\begin{array}{l}33.46 \\
40.01 \\
41.10 \\
40.81 \\
49.87\end{array}$ & 0.239 \\
\hline $\begin{array}{l}\text { Leukocytes } \\
\left(10^{3 /} \mu \mathrm{L}\right)\end{array}$ & $\begin{array}{c}\text { Negative Control } \\
1000 \mathrm{mg} / \mathrm{kg} \mathrm{BW} \\
2000 \mathrm{mg} / \mathrm{kg} \mathrm{BW} \\
\text { Satellite2000 mg/kg BW } \\
\text { Satellite Negative } \\
\text { Control } \\
\end{array}$ & $1.96-8.25$ & $\begin{array}{c}10.31 \\
1.96 \\
9.98 \\
10.04 \\
9.29\end{array}$ & 0.565 \\
\hline $\begin{array}{c}\text { Erythrocytes } \\
\left(10^{6} / \mu \mathrm{L}\right)\end{array}$ & $\begin{array}{c}\text { Negative Control } \\
1000 \mathrm{mg} / \mathrm{kg} \mathrm{BW} \\
2000 \mathrm{mg} / \mathrm{kg} \mathrm{BW} \\
\text { Satellite2000 } \mathrm{mg} / \mathrm{kg} \mathrm{BW} \\
\text { Satellite Negative } \\
\text { Control }\end{array}$ & $7.27-9.65$ & $\begin{array}{l}5.86 \\
7.83 \\
7.96 \\
7.71 \\
8.51\end{array}$ & 0.280 \\
\hline $\begin{array}{c}\text { Platelets } \\
\left(10^{3 /} \mu \mathrm{L}\right)\end{array}$ & $\begin{array}{c}\text { Negative Control } \\
1000 \mathrm{mg} / \mathrm{kg} \mathrm{BW} \\
2000 \mathrm{mg} / \mathrm{kg} \mathrm{BW} \\
\text { Satellite2000 } \mathrm{mg} / \mathrm{kg} \mathrm{BW} \\
\text { Satellite Negative } \\
\text { Control }\end{array}$ & $638-1.177$ & $\begin{array}{l}784 \\
638 \\
487 \\
645 \\
676\end{array}$ & 0.487 \\
\hline $\begin{array}{l}\mathrm{MCV} \\
(\mathrm{fL})\end{array}$ & $\begin{array}{c}\text { Negative Control } \\
1000 \mathrm{mg} / \mathrm{kg} \mathrm{BW} \\
2000 \mathrm{mg} / \mathrm{kg} \mathrm{BW} \\
\text { Satellite2000 } \mathrm{mg} / \mathrm{kg} \mathrm{BW} \\
\text { Satellite Negative } \\
\text { Control }\end{array}$ & $48.9-57.9$ & $\begin{array}{l}57 \\
53 \\
52 \\
53 \\
59\end{array}$ & 0.550 \\
\hline $\begin{array}{l}\mathrm{MCH} \\
(\mathrm{pg})\end{array}$ & $\begin{array}{c}\text { Negative Control } \\
1000 \mathrm{mg} / \mathrm{kg} \mathrm{BW} \\
2000 \mathrm{mg} / \mathrm{kg} \mathrm{BW} \\
\text { Satellite } 2000 \mathrm{mg} / \mathrm{kg} \mathrm{BW} \\
\text { Satellite Negative } \\
\text { Control }\end{array}$ & $17.1-20.4$ & $\begin{array}{l}21,4 \\
17,8 \\
18,7 \\
18,3 \\
19,7\end{array}$ & 0.679 \\
\hline $\begin{array}{l}\mathrm{MCHC} \\
(\mathrm{g} / \mathrm{dL})\end{array}$ & $\begin{array}{c}\text { Negative Control } \\
1000 \mathrm{mg} / \mathrm{kg} \mathrm{BW} \\
2000 \mathrm{mg} / \mathrm{kg} \mathrm{BW} \\
\text { Satellite2000 } \mathrm{mg} / \mathrm{kg} \mathrm{BW} \\
\text { Satellite Negative } \\
\text { Control }\end{array}$ & $32.9-37.5$ & $\begin{array}{l}37.5 \\
32.9 \\
36.2 \\
34.6 \\
33.7\end{array}$ & 0.755 \\
\hline
\end{tabular}


Table 5. Value of Hematological Parameters Analysis of Female Rat

\begin{tabular}{|c|c|c|c|c|}
\hline Parameter & Groups & $\begin{array}{c}\text { Normal Level } \\
\text { Female }\end{array}$ & $\begin{array}{l}\text { Grade } \\
\text { Value }\end{array}$ & $\begin{array}{l}\text { ANOVA } \\
(p>0.05)\end{array}$ \\
\hline $\begin{array}{l}\text { Hemoglobin } \\
(\mathrm{g} / \mathrm{dL})\end{array}$ & $\begin{array}{c}\text { Negative Control } \\
1000 \mathrm{mg} / \mathrm{kg} \mathrm{BW} \\
2000 \mathrm{mg} / \mathrm{kg} \mathrm{BW} \\
\text { Satellite2000 } \mathrm{mg} / \mathrm{kg} \mathrm{BW} \\
\text { Satellite Negative } \\
\text { Control }\end{array}$ & $13.7-16.8$ & $\begin{array}{l}12.4 \\
13 \cdot 2 \\
14 \cdot 3 \\
13 \cdot 0 \\
14.4\end{array}$ & 0.520 \\
\hline $\begin{array}{l}\text { Hematocrit } \\
(\%)\end{array}$ & $\begin{array}{c}\text { Negative Control } \\
1000 \mathrm{mg} / \mathrm{kg} \mathrm{BW} \\
2000 \mathrm{mg} / \mathrm{kg} \mathrm{BW} \\
\text { Satellite2000 mg/kg BW } \\
\text { Satellite Negative } \\
\text { Control }\end{array}$ & $37 \cdot 9-49 \cdot 9$ & $\begin{array}{l}34.42 \\
38.74 \\
38.57 \\
38.86 \\
44.11\end{array}$ & 0.122 \\
\hline $\begin{array}{l}\text { Leukocytes } \\
\left(10^{3 /} \mu \mathrm{L}\right)\end{array}$ & $\begin{array}{c}\text { Negative Control } \\
1000 \mathrm{mg} / \mathrm{kg} \mathrm{BW} \\
2000 \mathrm{mg} / \mathrm{kg} \mathrm{BW} \\
\text { Satellite2000 } \mathrm{mg} / \mathrm{kg} \mathrm{BW} \\
\text { Satellite Negative } \\
\text { Control }\end{array}$ & $1.13-7.49$ & $\begin{array}{l}7.24 \\
5.82 \\
6.17 \\
6.07 \\
5.74\end{array}$ & 0.437 \\
\hline $\begin{array}{c}\text { Erythrocytes } \\
\left(10^{6} / \mu \mathrm{L}\right)\end{array}$ & $\begin{array}{c}\text { Negative Control } \\
1000 \mathrm{mg} / \mathrm{kg} \mathrm{BW} \\
2000 \mathrm{mg} / \mathrm{kg} \mathrm{BW} \\
\text { Satellite2000 } \mathrm{mg} / \mathrm{kg} \mathrm{BW} \\
\text { Satellite Negative } \\
\text { Control }\end{array}$ & $7.07-9.03$ & $\begin{array}{l}5,87 \\
6,02 \\
7,23 \\
6,35 \\
7,27\end{array}$ & 0.552 \\
\hline $\begin{array}{l}\text { Platelets } \\
\left(10^{3 /} \mu \mathrm{L}\right)\end{array}$ & $\begin{array}{c}\text { Negative Control } \\
1000 \mathrm{mg} / \mathrm{kg} \mathrm{BW} \\
2000 \mathrm{mg} / \mathrm{kg} \mathrm{BW} \\
\text { Satellite2000 } \mathrm{mg} / \mathrm{kg} \mathrm{BW} \\
\text { Satellite Negative } \\
\text { Control }\end{array}$ & $680-1.200$ & $\begin{array}{l}442 \\
743 \\
394 \\
688 \\
537\end{array}$ & 0.077 \\
\hline $\begin{array}{l}\mathrm{MCV} \\
(\mathrm{fL})\end{array}$ & $\begin{array}{c}\text { Negative Control } \\
1000 \mathrm{mg} / \mathrm{kg} \mathrm{BW} \\
2000 \mathrm{mg} / \mathrm{kg} \mathrm{BW} \\
\text { Satellite2000 } \mathrm{mg} / \mathrm{kg} \mathrm{BW} \\
\text { Satellite Negative } \\
\text { Control }\end{array}$ & $49.9-58.3$ & $\begin{array}{l}59 \\
56 \\
53 \\
61 \\
61\end{array}$ & 0.111 \\
\hline $\begin{array}{l}\mathrm{MCH} \\
(\mathrm{pg})\end{array}$ & $\begin{array}{c}\text { Negative Control } \\
1000 \mathrm{mg} / \mathrm{kg} \mathrm{BW} \\
2000 \mathrm{mg} / \mathrm{kg} \mathrm{BW} \\
\text { Satellite2000 mg/kg BW } \\
\text { Satellite Negative } \\
\text { Control }\end{array}$ & $17.8-20.9$ & $\begin{array}{l}21.1 \\
20.2 \\
19.8 \\
20.4 \\
19.8\end{array}$ & 0.658 \\
\hline $\begin{array}{l}\text { MCHC } \\
(\mathrm{g} / \mathrm{dL})\end{array}$ & $\begin{array}{c}\text { Negative Control } \\
1000 \mathrm{mg} / \mathrm{kg} \mathrm{BW} \\
2000 \mathrm{mg} / \mathrm{kg} \mathrm{BW} \\
\text { Satellite2000 mg/kg BW } \\
\text { Satellite Negative } \\
\text { Control }\end{array}$ & $33.2-37.9$ & $\begin{array}{l}35 \cdot 9 \\
36.0 \\
37.1 \\
33.4 \\
32.7\end{array}$ & 0.010 \\
\hline
\end{tabular}


Male rats in the $2000 \mathrm{mg} / \mathrm{kg} \mathrm{BW}$ and satellite $2000 \mathrm{mg} / \mathrm{kg}$ BW groups experienced an increase in the production of leukocytes to fight infection or inflammation caused by immune system disorders ${ }^{16,17}$. In female rats in the 2000 $\mathrm{mg} / \mathrm{kg}$ BW satellite dose group, the MCV value increased due to a lack of folate/vitamin $\mathrm{B}_{12}$ nutrition and the possibility of liver infection, which could be examined through further histopathological examination. ${ }^{18,19}$

The suspension of ethanolic extract of black garlic in the negative control group, doses of $1000 \mathrm{mg} / \mathrm{kg} \mathrm{BW}, 2000 \mathrm{mg} / \mathrm{kg} \mathrm{BW}$, the negative control satellite group and the satellite group of $2000 \mathrm{mg} / \mathrm{kg} \mathrm{BW}$ in male and female white rats for 28 days to 42 days did not significantly affect blood levels, such as hemoglobin, hematocrit, leukocytes, erythrocytes, platelets, MCV, $\mathrm{MCH}$, and MCHC. A study on black garlic extract increased hematological parameters in high doses as observed in aged black garlic increasing blood cell counts and blood lipids in albino Wistar rats. $^{20}$

\section{CONCLUSION}

The study showed that black garlic ethanol extract had no significant effect or was at normal levels on hematological parameters. Therefore, it can be concluded that the ethanolic extract of black garlic is safe for human use as a treatment for hypercholesterolemia.

\section{ACKNOWLEDGMENT}

The author would like to thank Mr. Dr. apt. Yoppi Iskandar, M. Si. and Mrs. Dr. apt. Eli Halimah, M. Si, for assisting the author in completing this research.

\section{REFERENCES}

1. Adi, A. C., Salisa, W., Nuringtyas, D.P., Dini, I. E., Tawakal, A. I., Syahrul, F., et al. PENYULUHAN DAN PELATIHAN PEMBUATAN BAWANG PUTIH FERMENTASI DALAM RANGKA PENINGKATAN PRODUKTIFITAS KELOMPOK LANSIA. J Layanan Masy $J$ Public Serv. 2021;5(1):249-58. https://doi.org/10.20473/jlm.v5i1.202

\section{$1.249-258$}

2. Choi, I. S., Cha, H. S., Lee, Y. S. Physicochemical and antioxidant properties of black garlic. Molecules. 2014;19(10):16811-23.

https://doi.org/10.3390/molecules191 016811

3. Bae, S. E., Cho, S. Y., Won, Y. D., Lee, S. H., Park, H. J. A comparative study of the different analytical methods for analysis of S-allyl cysteine in black garlic by HPLC. LWT-Food Sci Technol. 2012;46(2):532-5.

https://doi.org/10.1016/j.Iwt.2011.11. 013

4. Zhao, N. N., Zhang, H., Zhang, X. C., Luan, X. B., Zhou, C., Liu, Q. Z., et al. Evaluation of acute toxicity of essential oil of garlic (Allium sativum) and its selected major constituent compounds against overwintering Cacopsylla chinensis (Hemiptera: Psyllidae). J Econ Entomol. 2013;106(3):1349-54.

https://doi.org/10.1603/EC12191

5. Permenkes RI. Formularium obat herbal asli indonesia. Biro Huk Dan Organ Kementrian Kesehat RI. 2016;

6. Kamaluddin, M. T. Obat Herbal Berkhasiat, Keamanan Perlu 
Dimonitor. J Indones Med Assoc. 2016;66(10):461-4.

7. Sasaki, J-I. Overview of the black garlic movement in the fields of research and marketing. J Life Sci. 2015;9:65-74.

https://doi.org/10.17265/19347391/2015.02.003

8. Wang, X., Jiao, F., Wang, Q-W., Wang, J., Yang, K., Hu, R-R., et al. Aged black garlic extract induces inhibition of gastric cancer cell growth in vitro and in vivo. Mol Med Rep. 2012;5(1):66-72. https://doi.org/10.3892/mmr.2011.588

9. Jeong, Y. Y., Ryu, J. H., Shin, J-H, Kang, M. J., Kang, J. R., Han, J., et al. Comparison of anti-oxidant and antiinflammatory effects between fresh and aged black garlic extracts. Molecules.2016;21(4):430.

https://doi.org/10.3390/molecules210 40430

10. Park, C., Park, S., Chung, Y. H., Kim, G-Y., Choi, Y. W., Kim, B. W., et al. Induction of apoptosis by a hexane extract of aged black garlic in the human leukemic U937 cells. Nutr Res Pract. 2014;8(2):132-7. https://doi.org/10.4162/nrp.2014.8.2.132

11. Ha, A. W., Ying, T., Kim, W. K. The effects of black garlic (Allium satvium) extracts on lipid metabolism in rats fed a high fat diet. Nutr Res Pract. 2015;9(1):30-6.

https://doi.org/10.4162/nrp.2015.9.1.30

12. Kim, M. J., Yoo, Y. C., Kim, H. J., Shin, S. K., Sohn, E. J., Min, A. Y., et al. Aged black garlic exerts anti-inflammatory effects by decreasing no and proinflammatory cytokine production with less cytoxicity in LPS-stimulated raw 264.7 macrophages and LPSinduced septicemia mice. J Med Food. 2014;17(10):1057-63.

https://doi.org/10.108g/jmf.2013.3043

13. Yoo, J-M., Sok, D-E., Kim, M. R. Antiallergic action of aged black garlic extract in $\mathrm{RBL}-2 \mathrm{H}_{3}$ cells and passive cutaneous anaphylaxis reaction in mice. J Med Food. 2014;17(1):92-102. https://doi.org/10.108g/jmf.2013.2927

14. Wahdaningsih, S., Untari, E. K., Robiyanto, R. Profil Hematologi pada Tikus Putih (Rattus norvegicus L.) Galur Wistar Setelah Pemberian Ekstrak Etanol Daun Bawang Dayak (Eleutherine americana (Aubl.) Merr. ex K. Heyne.). Pharm J Farm Indones. 2020;17(2):332-42.

https://doi.org/10.30595/pharmacy.v1 7 i2.7499

15. BPOM R. Non-clinical toxicity test guidelines in in vivo (Indonesian: Pedoman Uji Toksisitas Nonklinik Secara In vivo). Jkt Badan Pengawas Obat Dan Makanan Repub Indones. 2014;

16. Purnomo, D., Sugiharto, S., Isroli, I. Total leukosit dan diferensial leukosit darah ayam broiler akibat penggunaan tepung onggok fermentasi rhizopus oryzae pada ransum. J Ilmu-Ilmu Peternak Indones (J Anim Sci). 2015;25(3):59-68. https://doi.org/10.21776/ub.jiip.2015. $\underline{025.03 .08}$

17. Kim, M. J., Yoo, Y. C., Kim, H. J., Shin, S. K., Sohn, E. J., Min, A. Y., et al. Aged black garlic exerts anti-inflammatory effects by decreasing no and proinflammatory cytokine production with less cytoxicity in LPS-stimulated 
raw 264.7 macrophages and LPS-

induced septicemia mice. J Med Food.

2014;17(10):1057-63.

https://doi.org/10.108g/jmf.2013.3043

18. Kurniawati, Y. TOKSISITAS SUBKRONIS TABLET FRAKSI EA-96 HERBA SAMBILOTO (Andrographis paniculata Nees) PADA HATI DAN GINJAL TIKUS WISTAR [PhD Thesis]. Universitas Airlangga; 2016.

19. Septyasih, A. R. N., Widajanti, L., Nugraheni, S. A. Hubungan asupan zat besi, asam folat, vitamin B12 dan vitamin $C$ dengan kadar hemoglobin siswa di SMP Negeri 2 Tawangharjo Kabupaten Grobogan. J Kesehat Masy Undip. 2016;4(4):521-8. https://doi.org/10.14710/jkm.v4i 14.142 $\underline{82}$

20. Saba, I., Samia, S., Samia, K., et. al. Aged Black Garlic Extract Improves Blood Cell CountS. J Peoples Univ Med Health Sci. 2015;5(2):85-9. 